\title{
Frequency and pattern of migraine among medical and nursing students at Enugu, South East Nigeria
}

\author{
BA Ezeala-Adikai ${ }^{*}$, OS Ekenze, IO Onwuekwe \\ From The European Headache and Migraine Trust International Congress \\ London, UK. 20-23 September 2012
}

\section{Introduction}

Headache may be the commonest neurological disorder in the community and may impose a substantial burden on sufferers and on society. Although data from the last century revealed that primary headaches were rare among Africans, newer data have shown higher prevalence in the continent. Few studies have addressed the frequency of migraine among students in South East Nigeria

\section{Objective}

To ascertain the Frequency and pattern of migraine among young Nigerians as represented by medical and nursing students in two Teaching Hospitals and two Nursing Schools in Enugu, South East Nigeria.

\section{Methods}

This was a cross-sectional descriptive interview-based study using structured headache questionnaire. Consent was obtained and the results interpreted following the guidelines of the International Headache Society (II).

\section{Results}

The one year frequency of primary headache of any type was $86.3 \%$ ( $85.4 \%$ in males and $86.7 \%$ in females). The frequency of migraine was $13.1 \%$ (males $10.8 \%$, females $14.8 \%$ ). Frequency of migraine was highest below 20 years (16\%) (males $-8 \%$, females $18.8 \%$ ). The peak frequency for males was from the ages of 20 to 26 (15.3\%) and below 20 years for females (18.8\%). Most, migraine attacks were unilateral (89.8\%), moderate/severe (67.8\%), pulsating $96.6 \%$ ) with phono/photophobia $(83.1 \%)$ and stress as the commonest triggering factor (61\%).

University of Nigeria Teaching Hospital, Enugu, Nigeria
Migraine attacks were frequent in $66.1 \%$ and affected the quality of life of the sufferers in $40.7 \%$.

\section{Conclusion}

There is a high frequency of headache of migraine among medical and nursing students in Enugu. Migraine was 1.4 times commoner in females than in males. Migraine affected the quality of life of more than $40 \%$ of its sufferers.

Published: 21 February 2013

doi:10.1186/1129-2377-14-S1-P5

Cite this article as: Ezeala-Adikai et al.: Frequency and pattern of migraine among medical and nursing students at Enugu, South East Nigeria. The Journal of Headache and Pain 2013 14(Suppl 1):P5.

Submit your manuscript to a SpringerOpen ${ }^{\bullet}$ journal and benefit from:

- Convenient online submission

- Rigorous peer review

- Immediate publication on acceptance

- Open access: articles freely available online

- High visibility within the field

- Retaining the copyright to your article

Submit your next manuscript at $>$ springeropen.com

C 2013 Ezeala-Adikai et al; licensee Springer. This is an Open Access article distributed under the terms of the Creative Commons Attribution License (http://creativecommons.org/licenses/by/2.0), which permits unrestricted use, distribution, and reproduction in any medium, provided the original work is properly cited. 